\title{
Editorial: Improving, Bypassing or Overcoming Representation?
}

\author{
Pierre-Etienne Vandamme ${ }^{1 *}$, Jean-Benoit Pilet $^{1}$ and Camille Bedock ${ }^{2}$ \\ ${ }^{1}$ FNRS, Université Libre de Bruxelles, Brussels, Belgium, ${ }^{2}$ UMR5116 Centre Émile Durkheim Science Politique et Sociologie \\ Comparatives, Aquitaine, France
}

Keywords: representation, democratic innovations, participation, citizens, political theory

Editorial on the Research Topic

Improving, Bypassing or Overcoming Representation?

The discussion and empirical analysis of the increasing citizen dissatisfaction with existing representative institutions has become a central concern for political science in recent decades (Rosanvallon, 2006; Papadopoulos, 2013; Merkel, 2014; Thomassen, 2016). Political theory has also contributed to this debate by focusing increasingly on non-elective forms of participation and representation (Saward, 2009; Kuyper, 2016; Landemore, 2020). Paradoxically, there has not been a significant dialogue between political theory and empirical research that would aim to understand whether these non-elective forms of participation and representation are to be conceived as a complement, a diversion or even a full-blown alternative to electoral representation (Peters, 2016). Is representation dispensable? What are the alternatives to existing institutions? How are existing institutions and their alternatives perceived by citizens, parties and elected representatives? The aim of the present collection of articles was precisely to address these questions by means of a dialogue between political theory and empirical work on actors' perceptions.

A first set of articles deals with citizens' perceptions of their democratic institutions and with their normative aspirations. A theoretical contribution by Ramelet explains why citizens' participation in elections cannot meaningfully be interpreted as a form of consent to being represented, or to being represented through elections. As revealed by the empirical literature, voting can be motivated by a diversity of motivations, including strategic and expressive ones. Hence, the only way of knowing what citizens think about representation and elections and whether they see electoral representation as a legitimate embodiment of democratic ideals is to directly ask them. This is precisely what three other contributions to this e-book do.

Dolez examines citizens' representations of political actors and of their political regime through couple interviews with French citizens. She finds citizens mainly dissatisfied with political actors-and only indirectly with the regime -, who aspire to a better representation, but do not really question the delegation of power to representatives and fail to imagine alternatives to electoral representation. In the same spirit, the contribution by Bedock tries to understand citizens' aspirations about democracy through in-depth interviews with French citizens. She highlights four ideal-typical aspirations: entrustment of personalities distinguishing themselves from the mass and capable of surmounting partisan quarrels to govern efficiently; control and sanction of representatives who are usually detached from social reality and risk abusing from their privileges; identification with representatives who should be more diverse to better represent neglected interests; and finally more participation by citizens in decision-making to increase social progress. None of these discourses rejects representation entirely, but the latter three do question the way it currently works. The contribution by Pilet et al. and his colleagues also highlights a plurality of visions of democracy among citizens. Interestingly, it also shows that most citizens aspire to a governance model where decision-making power is shared by a plurality of actors: elected representatives and experts, elected representatives and citizens, or even experts and citizens. Hence, it seems to be the monopoly over representation by elected politicians that is questioned, more than representation or elections as such. 
A second set of articles explores different alternatives to traditional representative institutions and their role. The most often discussed is the new form of representation offered by deliberative mini-publics with randomly selected citizens. As Setälä explains in her contribution, these can perform a variety of functions aiming at improving electoral representation rather than replacing it: they can provide the advisory input resulting from an inclusive deliberative process in the process of political will-formation; organize deliberative collaboration between ordinary citizens and elected representatives; or scrutinize the work of elected representatives-each of these options coming with specific challenges that she discusses. Ireland recently witnessed several experiences with mini-publics, discussed in Courant's contribution. Interestingly, they evolved from a collaborative model, mixing randomly selected citizens with elected representatives, to a model that bypasses electoral representation: recommendations by the citizens' assembly are validated or rejected in a national referendum. Courant argues that Ireland is an interesting case of relatively strong institutionalization of deliberative mini-publics, but also highlights some limits of the Irish experiences and warns against the temptation to try to import their "model".

While sortition can be seen as offering an alternative form of political representation-not necessarily incompatible with elections -, other democratic innovations aim at improving electoral representation itself. This is the case of the recall, or the possibility for citizens to remove elected representatives from office before the end of their term. In his contribution, Vandamme argues that this mechanism could be a response to citizens' demand for more control over their representatives. However, because it is important for representatives to keep some room of maneuver and to avoid a systematic contestation of electoral results by sore losers, he argues that the recall is better conceived as a last resort mechanism that should not be too easy to enact. Valsangiacomo, however, presents and defends a very innovative model of representation-liquid democracy -, where citizens can choose either to be represented by "proxies" of their choice, subject to instant recall, or to vote directly on issues they are particularly interested in. This is meant to offer the best possible compromise between representation and direct legislation. Should such a model be adopted, however, it would importantly reshape the representative dynamic and, as she argues, bring political parties closer to interest groups.

\section{REFERENCES}

Bengtsson, Å., and Christensen, H. (2016). Ideals and Actions: Do Citizens' Patterns of Political Participation Correspond to Their Conceptions of Democracy? Gov. Oppos. 51 (2), 234-260. doi:10.1017/gov.2014.29

Kuyper, J. W. (2016). Systemic Representation: Democracy, Deliberation, and Nonelectoral Representatives. Am. Polit. Sci. Rev. 110 (2), 308-324. doi:10.1017/s0003055416000095

Landemore, H. (2020). Open Democracy: Reinventing Popular Rule for the TwentyFirst Century. Princeton, New Jersey: Princeton University Press. doi:10.2307/ j.ctv10crczs

Merkel, W. (2014). Is There a Crisis of Democracy? Democratic Theor. 1 (2), 11. doi:10.3167/dt.2014.010202

Papadopoulos, Y. (2013). Democracy in Crisis? Politics, Governance and Policy. London: Palgrave. doi:10.1007/978-1-137-34920-0

Peters, Y. (2016). Zero-Sum Democracy? the Effects of Direct Democracy on Representative Participation. Polit. Stud, 64 593-613. doi:10.1177/ 0032321715607510
Faced with this diversity of possible innovations, one question that arises is how representative claims can be authorized outside the framework of general elections. This question is taken up in the contribution by Guasti and Geissel, that traces representative claims in the election of a council of foreigners, in a participatory budgeting experience and in a referendum, all in Germany. One of their findings in all three cases is a significant discrepancy between the claimed constituency, the actually affected audience, and the legally enfranchised constituency, showing how claim-making is usually fractured and incomplete in representative processes.

Finally, anyone interested in the potential of democratic innovations to transform representative institutions is confronted with the question of what can motivate political actors to initiate such experimentations that have the potential to challenge their monopoly over representation. In their contribution, Junius et al. and his colleagues show that it is usually a combination of ideology, strategic interests and institutional factors that explain elected representatives' attitudes towards democratic innovations. Among other findings, left-wing parties are more supportive of different innovations, while opposition parties, and parties in consensual democracies in particular, are more favorable to referendums.

Overall, this collection of articles helps us see the diversity of possible innovations to traditional representative institutions and the different ways in which they can be articulated with the latter. Among other things, it also shows that a questioning of electoral representation does not necessarily entail a rejection of representation or elections. However, what seems more and more questioned by citizens and theorists is the monopoly of elected representatives over decisionmaking and their degree of independence. In that respect, the various contributions that are included here can enter in direct dialogue with studies on how to reform contemporary democracies to include new elements of citizens' participation, in various ways (Bengtsson and Christensen, 2016; Landemore, 2020).

\section{AUTHOR CONTRIBUTIONS}

All authors listed have made a substantial, direct, and intellectual contribution to the work and approved it for publication.

Rosanvallon, P. (2006). La contre-démocratie. La politique à l'âge de la défiance. Paris: Seuil.

Saward, M. (2009). Authorisation and Authenticity: Representation and the

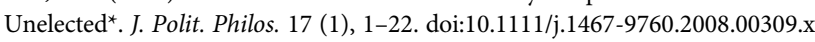
Thomassen, J. (2016). "What's Gone Wrong with Democracy, or with Theories Explaining Why it Has?", in Citizenship And Democracy In an Era Of Crisis. Editors P. Thomas, R. Sigrid, S. Rüdiger, and Z. Sonja. (London: Routledge), 34-52. doi:10.4324/9781315750248

Conflict of Interest: The authors declare that the research was conducted in the absence of any commercial or financial relationships that could be construed as a potential conflict of interest.

Copyright (C) 2021 Vandamme, Pilet and Bedock. This is an open-access article distributed under the terms of the Creative Commons Attribution License (CC BY). The use, distribution or reproduction in other forums is permitted, provided the original author(s) and the copyright owner(s) are credited and that the original publication in this journal is cited, in accordance with accepted academic practice. No use, distribution or reproduction is permitted which does not comply with these terms. 